\title{
Diagnozowanie konstrukcji lotniczych metodą prądów wirowych i metody modelowania sygnałów elektromagnetycznych
}

\section{The inspection of the aerospace structures with the eddy current method and electromagnetic signal modeling}

\section{Streszczenie}

Przedmiotem artykułu jest opracowanie nowych procedur wykrywania uszkodzeń w konstrukcjach lotniczych. Klasyczne podejście jest oparte na optymalizacji parametrów badania takich jak: częstotliwość oraz rozmiar i typ sondy. Jednakże wykrycie i charakterystyka występujących uszkodzeń jest trudne chociażby ze względu na budowę badanej struktury (np. występowanie rożnego rodzaju wzmocnień), czy też na istnienie całej gamy różnych uszkodzeń (może występować np. korozja w połączeniach międzywarstwowych, korozja ukryta, pęknięcia zmęczeniowe itp.). Dlatego postanowiono opracować metodę badawczą, usprawniająca proces diagnostyczny, oparta na połączeniu metody eksperymentalnej - prądów wirowych z symulacjami numerycznymi bazującymi na metodzie elementów skończonych (MES). Metoda ta pozwala na modelowanie sygnałów elektromagnetycznych oraz symulację rozkładu pól elektromagnetycznych w badanym materiale. Wyniki uzyskane dzięki zbudowanym w programie ANSYS układom sonda-próbka, w połączeniu z badaniami eksperymentalnymi, pozwolą w przyszłości na opracowanie narzędzia, które będzie wykorzystywane do przygotowywania procesu pomiarowo-diagnostycznego.
Dr inż. Justyna Szlagowska-Spychalska, dr inż. Wojciech Spychalski, prof. dr hab. inż. Krzysztof J. Kurzydłowski - Politechnika Warszawska, dr inż. Krzysztof Dragan - Instytut Techniczny Wojsk Lotniczych, dr inż. Dominik Kukla - Instytut Podstawowych Problemów Techniki PAN.

\section{Abstract}

In the article a novel approach for the damage detection of the aerospace structures is presented. The classical approach take into the consideration the optimalization of the inspection parameters such as frequency, size of the probe and potential probe type. Due to the influence of substructural elements such as reinforcements, different types of damages and damages overlapping (such as bottom of the top layer corrosion and the top of the bottom layer corrosion in multilayer structures) the damage characterization may be difficult. The article presents approach for the inspection based on the description of the electromagnetic signal distribution in the inspected materials using the numerical models based on the ANSYS software. Then the signal interaction with the structure will be presented and in the future works correlated with the measurements based on the eddy current and appropriate signal processing techniques.

\section{Wstęp}

Monitorowanie konstrukcji z uwagi na możliwość wystapienia uszkodzeń jest istotnym czynnikiem systemu eksploatacji statków powietrznych (SP) [1]. Obecnie stosowane techniki diagnostyczne obejmują w większości przeglądy wizualne lub przeglądy 
z wykorzystaniem metod badań nieniszczących (Non Destructive Testing - NDT) [2].

Stosowane metody przeglądów są czasochłonne i kosztowne, a wyniki badań zależne od tzw. czynnika ludzkiego (doświadczenia personelu wykonującego badania, temperatury otoczenia, oświetlenia, hałasu, konieczności demontażu niektórych elementów statku powietrznego itp.). Nowoczesne techniki diagnostyczne oparte na zautomatyzowanych badaniach nieniszczących znacząco zmniejszają liczbę składowych wpływających na zależność wyników badań od czynników zewnętrznych, jak również skracają czas badania.

Do głównych zjawisk mogących prowadzić do uszkodzenia katastroficznego SP zalicza się: korozję, zjawiska pękania z udziałem korozji (SCC - Stress Corrosion Cracking), zjawiska pękania pod wpływem cykli zmęczeniowych. W większości przypadków występują takie uszkodzenia jak: pęknięcia zmęczeniowe pod łbem nitu w połączeniach nitowych, małe pęknięcia zmęczeniowe (MSD - Multiple Site Damage) prowadzące do powstania zjawiska rozległego uszkodzenia zmęczeniowego (WFD - Widespread Fatigue Damage), korozja ukryta, pęknięcia i korozja w połączeniach wielowarstwowych, a także zjawisko pękania pod wpływem naprężeń i korozji [3]. W większości rozważanych przypadków dotyczących diagnostyki nieniszczącej pęknięć zmęczeniowych dominuje metoda prądów wirowych. Wykorzystanie tej metody jest związane z paramagnetycznymi właściwościami badanych stopów aluminium, umożliwiających ich badanie tą metoda. Ponadto uszkodzenie o charakterze pęknięcia stanowi wadę prostopadle ułożoną $w$ stosunku do generowanych w materiale ścieżek prądów wirowych, co ułatwia ich detekcję.

Badanie metodą prądów wirowych ma charakter porównawczy i wymaga kalibracji. Stanowi to istotne ograniczenie zwłaszcza w przypadku diagnostyki elementów o złożonej geometrii. Współczesny rozwój metod symulacji numerycznych pozwala na stworzenie modeli umożliwiających wyznaczenie rozkładu pól elektromagnetycznych oraz obliczenie charakterystyk prądowirowych, które mogą stanowić dodatkowe usprawnienie procesu diagnostyczno-pomiarowego.

Możliwości zastosowania metody elementów skończonych (MES) do analizy zjawisk elektromagnetycznych i do obliczeń rozkładu prądów wirowych rozpoznano na początku lat 80 ub.w. [4]. Pierwsze prace w tym zakresie były oparte na prostych, dwuwymiarowych modelach i pozwalały uzyskać mapy rozkładów natężenia pola elektromagnetycznego i gęstości prądu [5]. W kolejnych latach zaczęto badać rozkłady pól wokół defektów w materiałach [6]. W ostatnim dziesięcioleciu rozwój metod numerycznych i wzrost mocy obliczeniowej komputerów pozwolił na rozważanie bardziej złożonych zagadnień, takich jak np. modelowanie analizy zmian impedancji sondy pomiarowej i związanej $z$ tym możliwości dokładniejszego wyznaczania charakterystyk prądowirowych [7]. Podjęto również próby analizy rozkładu gęstości prądów wirowych dla warstw wierzchnich i powłok, przy czym prace w tym zakresie prowadzono głównie dla elementów o prostych kształtach i dla materiałów o znacznych różnicach w konduktywności elektrycznej $[8,9]$. Pojawiły się również prace poświęcone modelowaniu i analizie pęknięć [10]. Coraz częściej podejmowane są próby modelowania rozkładu pola elektromagnetycznego dla modeli trójwymiarowych, przy czym rozpatrywane są rozkłady dla układów wielowarstwowych [11], dla materiałów o małej różnicy konduktywności elektrycznej pomiędzy warstwą a podłożem [12], a także dla przypadku występowania różnego rodzaju ubytków materiału w detalu $[13,14]$. Tego rodzaju analizy stanowią pierwszy krok na drodze do zastosowań przemysłowych. Możliwość połączenia metod nieniszczących z numerycznymi ma ogromne znaczenie dla przemysłu, zwłaszcza dla branży lotniczej, w której diagnostyka krytycznych elementów konstrukcji to podstawa.

\section{Modelowanie prądów wirowych}

Modelowanie przeprowadzono metodą elementów skończonych przy użyciu programu ANSYS 12. Stworzone zostały dwuwymiarowe modele układu sonda-próbka, umożliwiające symulacje rozkładu gęstości prądów wirowych w zależności od geometrii uszkodzenia, właściwości warstwy, geometrii próbki itp. Modele te stanowią bazę wyjściową dla dalszych bardziej złożonych symulacji pozwalających na: (1) modelowanie rozkładu pól elektromagnetycznych wokół najczęściej występujących w lotnictwie uszkodzeń (np. pęknięcia zmęczeniowe, korozja w połączeniach międzywarstwowych) oraz (2) wyznaczenie sygnału elektromagnetycznego, z którego określić zależność „kąt fazowy - uszkodzenie” lub „kąt fazowy - grubość warstwy".

W modelowaniu zjawisk elektromagnetycznych metodą elementów skończonych, za pomocą programu ANSYS, można dokonać wyboru pomiędzy dwiema formułami obliczeń (dla modelu 2D). Pierwsza polega na wykorzystaniu skalarnego potencjału pola magnetycznego ( $T$ - elektryczny potencjał wektorowy), ( $\Omega$ - skalarny potencjał magnetyczny [15]), druga na wykorzystaniu magnetycznego potencjału wektorowego(A - magnetyczny potencjał wektorowy), (V - skalarny potencjał pola elektrycznego - A, $[16,17]$.

Wybrane elementy i rodzaj rozwiązania z góry determinują metodę obliczeń (harmoniczna, zmienna $\mathrm{w}$ czasie - transient). $\mathrm{W}$ pracy obliczenia prowadzono w oparciu o magnetyczny potencjał wektorowy (MVP - Magnetic Vector Potential Formulation).

Aby lepiej zrozumieć przebieg obliczeń, należy przypomnieć fundamentalne równania opisujące zjawiska elektromagnetyczne, czyli równania Maxwella. W rozpatrywanym przypadku pomijane jest występowanie prądów przesunięcia i konwekcji $[18,19]$ wobec czego otrzymuje się trzy równania, które mają następującą postać: 
- prawo Faradaya:

$$
\nabla \times\{E\}=-\left\{\frac{\partial B}{\partial t}\right\}
$$

- prawo Ampera:

$$
\nabla \times\{H\}=\left\{J_{t}\right\}=\left\{J_{S}\right\}+\left\{J_{e}\right\}
$$

- prawo Gaussa dla magnetyzmu

$$
\nabla \times\{B\}=0
$$

gdzie: B - indukcja magnetyczna; T, E - natężenie pola elektrycznego, $\mathrm{V} / \mathrm{m} ; \mathrm{H}$ - natężenie pola magnetycznego, $\mathrm{A} / \mathrm{m}, \mathrm{J}_{\mathrm{t}}$ - całkowita gęstość prądu; $A / \mathrm{m}^{2} ; J_{\mathrm{s}}$ - gęstość prądu źródła; $J_{\mathrm{e}}$ - gęstość prądów wirowych; $t$-czas, $s ; V$ - divergence operator $1 / m, V_{x}$ - curl operator $1 / m$.

Jak można zauważyć dywergencja B jest zawsze równa zeru (3). Oznacza to, że pole B można przedstawić w postaci rotacji innego pola (4)

$$
\{B\}=\operatorname{rot} A=\nabla x\{A\}
$$

gdzie: A - magnetyczny potencjał wektorowy, Wb/m. W tym kontekście w obliczeniach wprowadzone jest pole A (magnetyczny potencjał wektorowy).

Jeśli wprowadzi się dodatkowe warunki brzegowe opisane równaniem (5) oraz potencjał skalarny pola elektrycznego $\vee$ opisany zależnością (6), oba równania Maxwella (1) i (3) są spełnione:

$$
\begin{aligned}
& c^{2} \nabla \cdot A+\frac{\partial V}{\partial t}=0 \\
& \{E\}=-\left\{\frac{\partial A}{\partial t}\right\}-\nabla \cdot V
\end{aligned}
$$

gdzie: V - potencjał skalarny pola elektrycznego, V.

Następnie, uwzględniając podstawowe prawo opisane równaniem (7) oraz dywergencję gęstości prądu, prawo Ampera (2) również jest spełnione:

$$
\{H\}=\frac{1}{\mu}\{B\}
$$

gdzie: $\mu$ - przenikalność magnetyczna, $\mathrm{H} / \mathrm{m}$.

Wtedy pierwszym wynikiem obliczeń jest rozkład indukcji magnetycznej B (4) następnie na tej podstawie wyliczane jest natężenie pola magnetycznego $H(7)$, a gęstość indukowanych prądów wirowych wyznaczana jest $z$ równania (8):

$$
\left\{J_{e}\right\}=-\gamma\left\{\frac{\partial A}{\partial t}\right\}
$$

gdzie $\gamma$ - konduktywność, $S / m$

\section{Modelowanie rozkładu gęstości prądów wirowych i sygnału przetwornika wiroprądowego - próbka z uszkodzeniem}

Badania i symulacje sprawdzające poprawność działania modelu, przeprowadzono dla próbki wzorcowej,wykorzystywanej do wykrywania ubytków korozyjnych z oznaczonymi 4 modelami ubytków o głębokościach odpowiednio: 0,12 (2); 0,21 (5); 0,32 (18) i 0,4 mm (rys. 1).

Próbka była wykonana z aluminium 3103. Na potrzeby symulacji numerycznych wyznaczono konduktywność badanego materiału (tabl. I).

Badania wykonano dla dwóch częstotliwości: 5 i 7 kHz z uwagi na możliwość zaplanowania wszystkich uszkodzeń próbki poddanej badaniom. Symulowany był ruch sondy po powierzchni próbki zawierającej uszkodzenie. Na rysunkach 2 i 3 przedstawiono przykładowe rozkłady gęstości prądów wirowych uzyskane dla próbki bez defektu oraz dla kolejnych przypadków z uszkodzeniami (dla jednego z położeń sondy). Wyraźnie można zaobserwować zjawisko „opływania” uszkodzenia przez prądy indukowane w materiale.

Symulacja numeryczna sygnałów przetwornika prądowirowego od uszkodzenia wiązała się z uzyskaniem rozwiązań dla kolejnych położeń sondy względem badanego materiału (ok. 10 lokalizacji dla każdego przypadku). Dla wszystkich położeń obliczano impedancję sondy. Aby znormalizować charakterystyki zmian impedancji przetwornika wiroprądowego otrzymane podczas symulacji, wyznaczono reaktancja sondy $\left(\omega L_{0}\right)$. W tym celu przeanalizowany został przypadek pracy przetwornika w kontakcie z materiałem nieuszkodzonym (tzw. „zerowanie sondy"). Uzyskane w ten sposób charakterystyki przetwornika prądowirowego dla rozpatrywanych uszkodzeń przedstawiono na rysunkach 4 i 5.

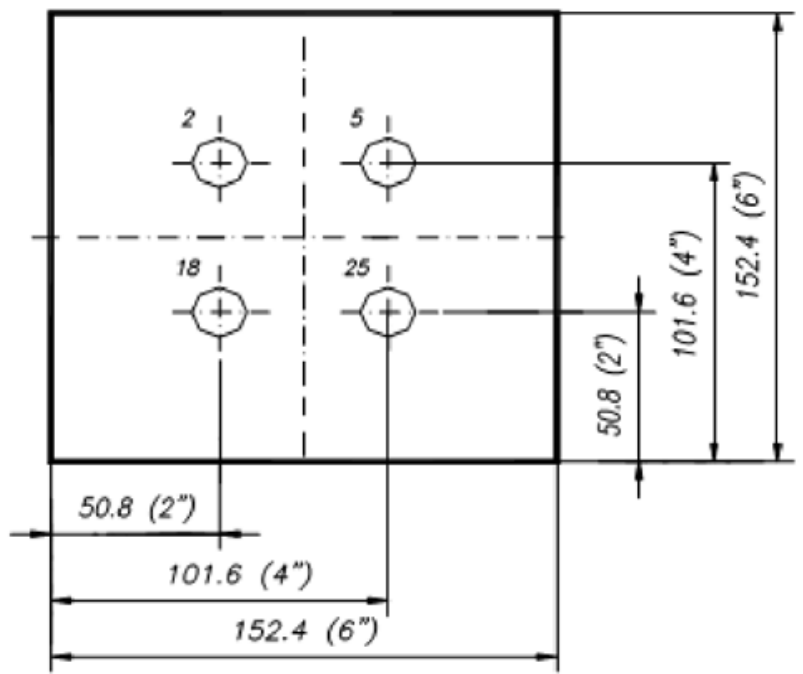

Rys. 1. Próbka wzorcowa do wykrywania uszkodzeń korozyjnych Fig. 1. Sample for corrosion damage identification

Tablica I. Właściwości materiałowe stopu aluminium 3103 wykorzystywane w symulacjach

Table I. Aluminum 3103 properties used for tests

\begin{tabular}{|c|c|}
\hline Właściwości & Stop aluminium 3103 \\
\hline Rezystywność, $\Omega \mathrm{m}$ & $(5,51 \pm 2) \times 10^{-8}$ \\
\hline Konduktywność, $\mathrm{S} / \mathrm{m}$ & $(18,2 \pm 0,1) \times 10^{6}$ \\
\hline Przenikalność magnetyczna, $\mu \mathrm{r}$ & 1 \\
\hline
\end{tabular}


Uzyskane mapy rozkładu gęstości prąów wirowych, jak również kształt otrzymanych krzywych, pozwoliły przyjąć założenie, że warunki brzegowe
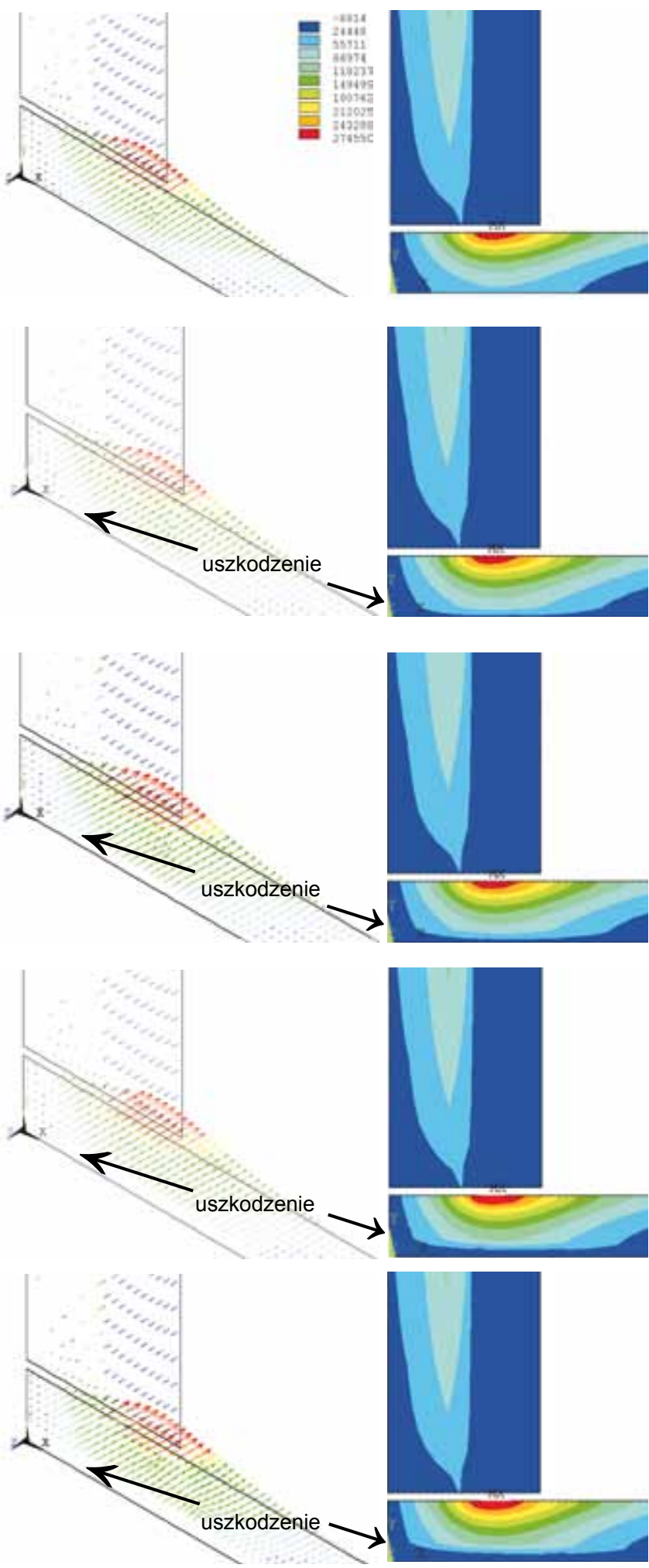

Rys. 2. Wektorowe i konturowe mapy rozkładu gęstości prądów wirowych $\left(\mathrm{A} / \mathrm{m}^{2}\right)$, przy częstotliwości badania $5 \mathrm{kHz}$, dla próbki:a) bez uszkodzenia i z uszkodzeniem: b) 0,12 mm; c) 0,21 mm; d) 0,32 mm; e) $0,40 \mathrm{~mm}$

Fig. 2. Vectorial and contour maps of the distribution of eddy current density $\left(\mathrm{A} / \mathrm{m}^{2}\right)$, at a frequency of $5 \mathrm{kHz}$ for sample: a) without and with damage b) $0.12 \mathrm{~mm}$, c) $0.21 \mathrm{~mm}$, d) $0,32 \mathrm{~mm}$, e) $0.40 \mathrm{~mm}$ symulacji numerycznych zostały dobrane prawidłowo, wobec tego postanowiono przejść do kolejnego etapu badań, jakim była weryfikacja zbudowanego modelu z rzeczywistymi pomiarami.
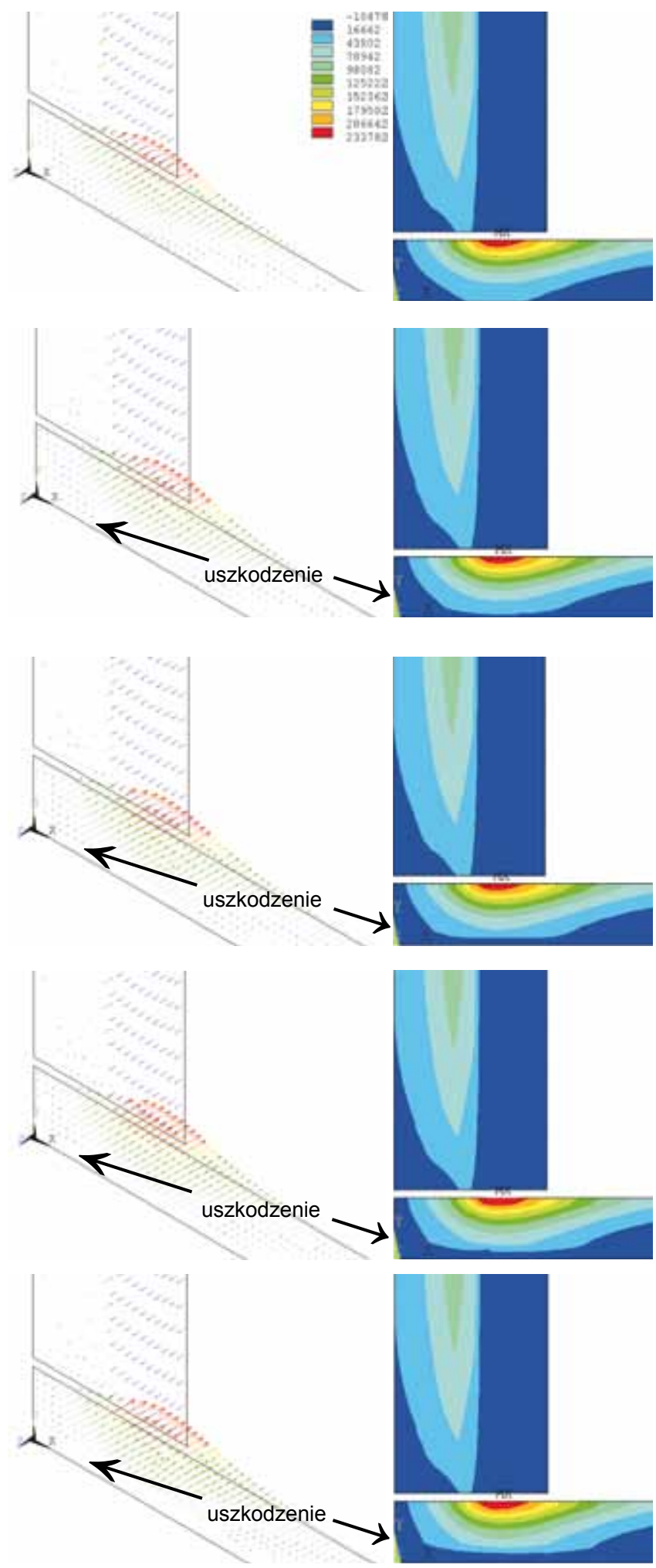

Rys. 3. Wektorowe i konturowe mapy rozkładu gęstości prądów wirowych $\left(\mathrm{A} / \mathrm{m}^{2}\right)$, przy częstotliwości badania $7 \mathrm{kHz}$, dla próbki: a) bez uszkodzenia i z uszkodzeniem: b) 0,12 $\mathrm{mm}$; c) 0,21 mm; d) 0,32 mm; e) $0,40 \mathrm{~mm}$

Fig. 3. Vectorial and contour maps of the distribution of eddy current density $\left(\mathrm{A} / \mathrm{m}^{2}\right)$, at a frequency of $7 \mathrm{kHz}$ for sample: a) without and with damage b) $0.12 \mathrm{~mm}, \mathrm{c}) 0.21 \mathrm{~mm}, \mathrm{~d}) 0,32 \mathrm{~mm}$, e) $0.40 \mathrm{~mm}$ 


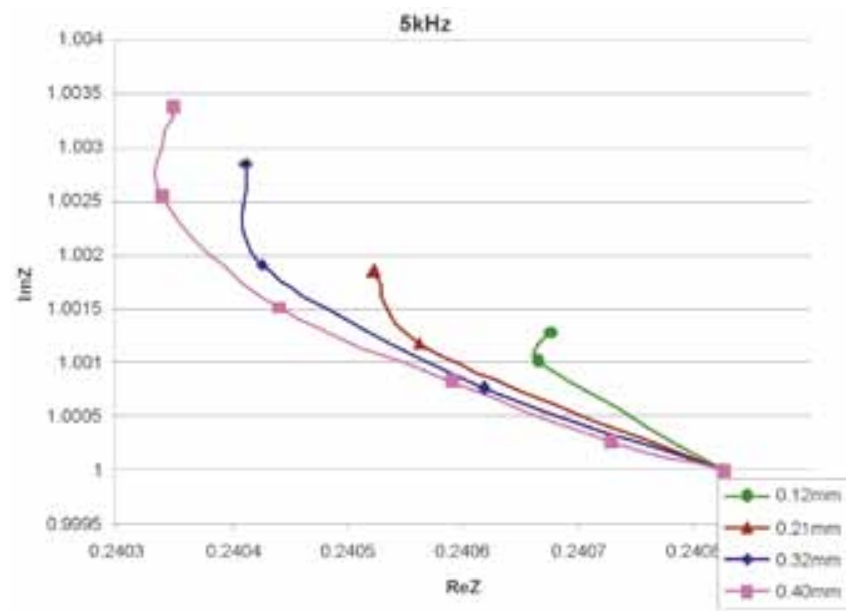

Rys. 3. Obliczone charakterystyki przetwornika wiroprądowego dla kolejnych wielkości uszkodzeń, częstotliwość $5 \mathrm{kHz}$

Fig. 3. Calculated eddy current transducer characteristics for subsequent extent of damage, frequency of $5 \mathrm{kHz}$

$7 \mathrm{kHz}$

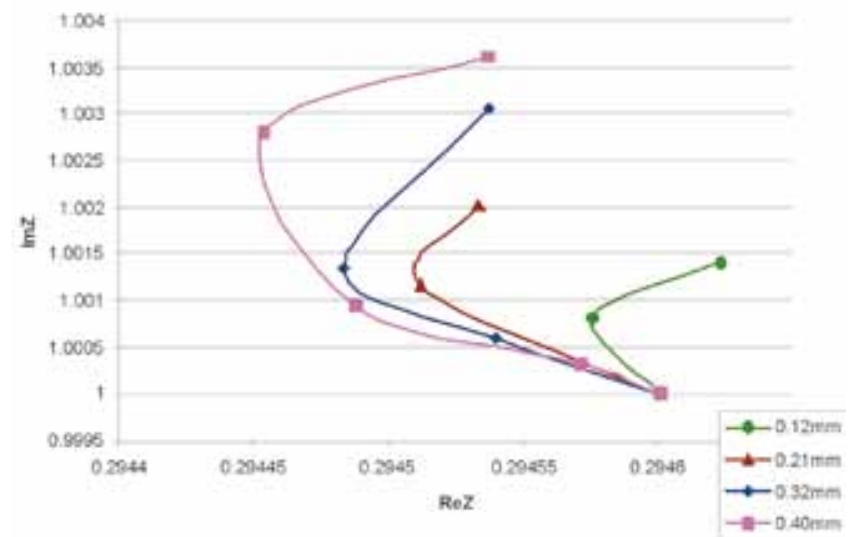

Rys. 5. Obliczone charakterystyki przetwornika wiroprądowego dla kolejnych wielkości uszkodzeń, częstotliwość $7 \mathrm{kHz}$

Fig. 5. Calculated eddy current transducer characteristics for subsequent extent of damage, frequency of $7 \mathrm{kHz}$

\section{Weryfikacja wyników}

Weryfikacji modelu dokonano na podstawie badań wiroprądowych. Pomiary wykonano za pomocą sondy zamodelowanej podczas badań numerycznych. Do pomiarów użyto defektoskopu prądowirowego - Phasec 2200 D. Rejestrowane dane zapisywano w postaci plików obrazowych, co pozwoliło na ich wykreślenie w arkuszach kalkulacyjnych (środowiskach obliczeń numerycznych).

Tablica II. Kąty fazowe otrzymane na podstawie symulacji oraz pomiarów dla częstotliwości $5 \mathrm{kHz}$

Table II. Phase angles obtained from simulations and measurements for a frequency of $5 \mathrm{kHz}$

\begin{tabular}{|c|c|c|}
\hline $\begin{array}{c}\text { Głębokość } \\
\text { uszkodzenia, } \mathrm{mm}\end{array}$ & $\begin{array}{c}\text { Wyniki symulacji } \\
\text { (tg kąta fazowego) }\end{array}$ & $\begin{array}{c}\text { Wyniki pomiarów } \\
\text { (tg kąta fazowego) }\end{array}$ \\
\hline 0,12 & 0,158934 & 2,190476 \\
\hline 0,21 & 0,163519 & 2,39024 \\
\hline 0,32 & 0,209779 & 3,05 \\
\hline 0,40 & 0,254136 & 3,7 \\
\hline
\end{tabular}

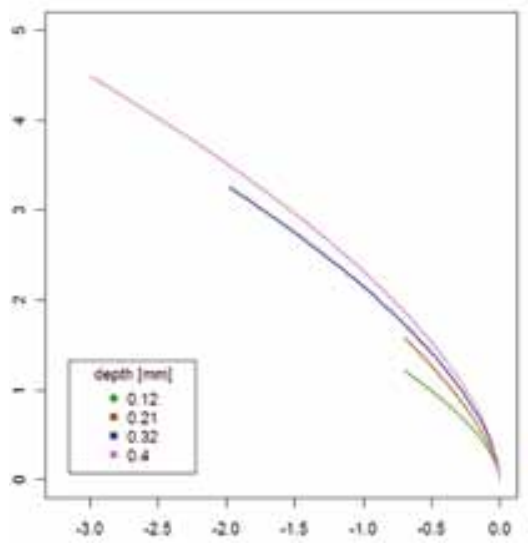

Rys. 6. Wyniki pomiarów dla częstotliwości $5 \mathrm{kHz}$ Fig. 6. Results at the frequency of $5 \mathrm{kHz}$

Dane z pomiarów korelowano za pomocą modelu liniowego opisującego przebieg prostej dla punktu łączącego punkt największej wypukłości z początkiem obranego układu współrzędnych.

Poniżej przedstawiono opis korelacji wyników z pomiarów (częstotliwość $5 \mathrm{kHz}$ z przedstawionym już modelem).

$\mathrm{Na}$ rysunku 6 przedstawiono krzywe fazowe uzyskane z pomiarów z częstotliwością $5 \mathrm{kHz}$. Zgodność wyników (dla przedstawionych krzywych fazowych: pomiar - rys. 6 i model - rys. 4) oceniać można na podstawie wartości kąta fazowego dla wybranych punktów na krzywej. Jednakże należy pamiętać, że bezpośrednie porównanie nie będzie możliwe $\mathrm{z}$ uwagi na założenia modelu. Poniżej przedstawiono metodykę wyznaczenia sposobu porównania sygnałów z modelu i pomiaru.

Jednym z możliwych wyborów jest ustalenie punktu stanowiącego 95 centyl amplitudy (lub amplitudę maksymalną), medianę lub punkt największej wypukłości krzywej $P_{w}$, maksymalizującego odległość od odcinka łączącego początek $\mathrm{P}_{\mathrm{i}}$ i koniec $\mathrm{P}_{\mathrm{f}}$ krzywej fazowej $l$ :

$$
p_{w}=\underset{l}{\arg \max } d\left(p, p_{i} p_{f}\right)
$$

Przedstawiono porównanie krzywych fazowych opracowane na podstawie przyjętego kryterium (tabl. II).

Ze względu na trudności w odwzorowaniu w modelu rzeczywistego kształtu sondy oraz dokładnej charakterystyki materiałowej badanych próbek kąty fazowe otrzymane dla uszkodzeń różnią się. Dlatego do weryfikacji zastosowano przyrosty (zmiany kątów fazowych dla różnych uszkodzeń). Wyniki porównania przedstawiono w tablicy III.

Obliczone przyrosty kąta fazowego wraz ze wzrostem głębokości uszkodzenia pozostają w bardzo dobrej zgodności z doświadczeniem. Można zatem stwierdzić, że wpływ zmiany parametrów pęknięcia na

Tablica III. Przyrost tg kąta fazowego dla poszczególnych pęknięć Table III. The increase of the phase angle tan for individual cracks

\begin{tabular}{|c|c|c|}
\hline $\begin{array}{c}\text { Głębokość } \\
\text { uszkodzenia, } \mathrm{mm}\end{array}$ & Wyniki symulacji & Wyniki pomiarów \\
\hline 0,21 & $2,8 \%$ & $8,4 \%$ \\
\hline 0,32 & $22,1 \%$ & $21,6 \%$ \\
\hline 0,4 & $17,45 \%$ & $17,57 \%$ \\
\hline
\end{tabular}


uzyskiwane krzywe fazowe jest dobrze odwzorowany w opracowanym modelu. Uzyskany wynik będzie ponadto korelowany z pomiarami dla różnych zakresów częstotliwości. Ma to szczególnie znaczenie dla dalszej pracy związanej z tworzeniem modeli dla bardziej złożonych struktur.

\section{Wnioski i walidacje}

Podsumowując przeprowadzone badania należy stwierdzić, że zaproponowana metoda oparta na wykorzystaniu formalizmu metody elementów skończonych do zbudowania modeli pozwalających uzyskać ilościowy opis prądów wirowych, będący podstawą określenia charakterystyk sygnałowych, jest właściwa.

Zasadność zastosowanej metody potwierdzają następujące wyniki:

- uzyskane numerycznie charakterystyki przetwornika wiroprądowego od uszkodzeń mają kształt właściwy dla aluminium oraz są zgodne z charakterystykami otrzymanymi w czasie badań weryfikujących (rys. $3 \div 6$ );

- zmiany w różnicach pomiędzy kątami fazowymi uzyskane za pomocą modelowania są zgodne z zmianami określonymi podczas walidacji pomiarowej (wyniki przedstawiono w tablicach II i III).

- uzyskane wyniki pozwalają stwierdzić zgodność modelu z wynikami doświadczalnymi. Walida- cję przeprowadzono również dla częstotliwości $7 \mathrm{kHz}$, gdzie także uzyskano bardzo dobrą zgodność zmierzonych wartości.

Dalsze badania wykorzystujące metodę prądów wirowych, wspartą wynikami symulacji metodą elementów skończonych, będą się skupiały na:

- dalszej weryfikacji modelu dla innych przypadków uszkodzeń;

- stworzeniu bazy wyników obliczeń numerycznych stanowiących wzorce do pomiarów eksperymentalnych, co może znaleźć szczególne zastosowanie przy badaniach elementów wykonanych z różnych materiałów i o skomplikowanych kształtach;

- stworzeniu bazy charakterystyk sygnałowych dla konkretnych przypadków (np. dla różnego rodzaju wad i uszkodzeń, pęknięcia, wtrącenia itp.);

- stworzeniu narzędzia, które będzie wykorzystywane do przygotowywania procesu pomiarowo-diagnostycznego.

\section{Literatura}

[1] Dragan K., Klimaszewski S.: Problemy Badań i Eksploatacji Techniki Lotniczej. Tom 6 (rozdział 3) - Nowoczesne metody badań nieniszczących, Wydawnictwo Instytutu Technicznego Wojsk Lotniczych, 2006.

[2] Alten F., Grandt Jr.: Fundamentals of Structural Integrity. Damage Tolerant Design and Nondestructive Evaluation, Wiley, 2004.

[3] Aging of U.S. Air Force Aircraft - final report, Washington D.C. 1997.

[4] Palanisamy R., Lord W.: Finite Element Modeling of Electromagnetic NDT Phenomena, IEEE Transactions on Magnetics, vol. mag. 15 , no. 6, 1979.

[5] Nehl T.W., Demerdash N. A.: Application of finite element eddy current analysis to nondestructive detection of flaws in metallic structures, IEEE Transactions on Magnetics, vol. mag. 16, no. 5, 1980.

[6] Lord W.: Applications of numerical field modeling to electromagnetic methods of nondestructive testing, IEEE Transactions on Magnetics, vol. mag. 19, no. 6, 1983.

[7] Shin Y., Lee J., Song M.: Preparation of Eddy Current Impedance Plane Diagram by Finite Element Modeling, Key Engineering Materials, vols. 270-273, 2004.

[8] Starzyński G.: Warstwa wierzchnia i jej modelowanie, VIII Seminarium Szkoleniowe nt. Nieniszczące badania materiałów, Zakopane 2002

[9] Gotom Y., Matsuoka A., Takahashi N.: Measurement of thickness of nickel - layer on steel using electromagnetic method, IEEE Transactions on Magnetics, vol. 43, no. 6, 2007.

[10] Rachek M., Feliachi M.: 3D movement simulation techniques using FE methods: Application to Eddy current non-destructive testing, NDT\&E International, vol. 40, 2007.

[11] Yong Li, Theodoulidis T., Tian Gui Yun: Magnetic Field-Based Eddy-Current Modeling for Multilayered Specimens, IEEE
Transactions on Magnetics, vol. 43, Issue: 11, s. 4010-4015, 2007.

[12] Szlagowska-Spychalska J.: Modelowanie i pomiar prądów wirowych w warstwach hartowanych indukcyjnie pod kątem pomiarów ich grubości w elementach o złożonych kształtach Politechnika Warszawska, rozprawa doktorska, 2009.

[13] Marklein R., Rahman M. U.: Numerical modeling and inverse profiling in non-destructive testing, Applied Electromagnetics Conference (AEMC), s. 1-4, 2009.

[14] Thomas V., Joubert P.Y., Vourc'h E., Placko D.: A novel modeling of surface breaking defects for eddy current quantitative imaging, Sensors Applications Symposium (SAS), IEEE, s. 154-157, 2010.

[15] Sawicki B.: Modelowanie prądów wirowych w środowisku słaboprzewodzącym z wykorzystaniem wektorowego potencjału elektrycznego T, Politechnika Warszawska, rozprawa doktorska, 2003.

[16] Biro O., Preis K.: On the Use of the Magnetic Vector Potential in the Finite Element Analysis of Three - Dimensional Eddy Currents, IEEE Transactions on Magnetics, vol. 25, no. 4, 1989.

[17] Biro O., Preis K., Richter K.: On the Use of the Magnetic Vector Potential in the Nodal and Edge Finite Element Analysis of 3D Magnetostatic Problems, IEEE Transactions on Magnetics, vol. 32, no. 3, 1996.

[18] Renhart W., Stogner H., Preis K.: Calculation of 3D Eddy Current Problems by Finite Element Method using either an electric or a magnetic vector potential, IEEE Transactions on Magnetics, vol. 24, no. 1, 1988.

[19] Burais N., Foggia A., Nicolas A., Sabonnadiere J. C.: Electromagnetic Field Formulation for Eddy Current calculations in Nondestructive Testing System, IEEE Transactions on Magnetics, vol. mag. 18 , no. 6 . 